\title{
Synthetic Melanoma-Associated Antigens Vaccine
}

National Cancer Institute

\section{Source}

National Cancer Institute. Synthetic Melanoma-Associated Antigens Vaccine. NCI

Thesaurus. Code C48639.

A cancer vaccine containing synthetic epitope peptides derived from melanoma tumorassociated antigens (TAAs), including melanoma-melanocyte antigen gp100(280-288), melanoma-associated antigen tyrosinase(1-9), and melanoma-associated antigen melan-A(27-35). Upon administration, synthetic melanoma-associated antigens vaccine may stimulate a cytotoxic T-lymphocyte immune response ag ainst melanoma cells that express TAAs which share epitopes with the vaccine epitope peptides, resulting in tumor cell lysis. 